УДК $378.091 .313-057.87$

DOI:

Роман Попов, кандидат наук з державного управління,

дочент кафедри романо-германських мов і перекладу

Національного університету біоресурсів і природокористування Украӥни

\title{
СУКУПНІСТЬ ПРИНЦИПІВ РОЗВИТКУ АВТОНОМНОСТІ СТУДЕНТІВ В УМОВАХ ІНТЕГРАЦІЇ ОСВІТНЬОЇ Й САМООСВІТНЬОЇ ДІЯЛЬНОСТІ
}

У статті здійснюється аналіз сукупності принципів розвитку автономності студентів в умовах інтеграції освітньої й самоосвітньої діяльності. За умови впливу сочіального прогресу й новітніх наукових досягнень, виокремлення нових закономірностей навчання, накопичення досвіду роботи тих, хто навчає, й аналізу результатів навчання тих, хто навчається, певні принципи навчання видозмінюються, удосконалюються. Сучасні принципи зумовлюють вимоги до всіх компонентів навчального прочесу: иілей $i$ завдань, формування змісту, добору форм і методів, стимулювання, планування й аналізу результатів, які вже досягнуто.

Ключові слова: розвиток; автономність; студент; інтеграція; освітня діяльність; самоосвітня діяльність; вища школа.

Puc. 1. Лim. 11.

Roman Popov, Ph.D.(Public Administration), Associate Professor of the Romance and Germanic Languages and Translation Department, National University of Life and Environmental Sciences of Ukraine

\section{ABODY OF PRINCIPLES OF STUDENTS'AUTONOMY DEVELOPMENT IN THE CONTEXT OFINTEGRATION OF EDUCATIONALAND SELF-EDUCATIONALACTIVITIES}

The article analyzes the body of principles of the students' autonomy development in the context of integration of educational and self-educational activities. Under the influence of social progress and the latest scientific achievements, the selection of new common factors of learning, the accumulation of the experience of those who teach, and the analysis of the learning outcomes of those who learn, certain principles of education are modified and improved. Modern principles determine the requirements for all components of the learning process: the goals and objectives, the formation of the content, the selection of forms and methods, stimulation, planning and analysis of the results that have already been achieved.

All the knowledge which students gain within their individual educational activity has to be presented in modern, understandable renderings; the history of science, modern theories and possible expectations, offered by science, especially those which concern the possible ways to reach harmony between nature and people, may all serve as the subjects of studies.

The conducted analysis of the paradigm of principles of individualism; humanization and humanitarization, succession; scientific character; consciousness and activeness; systematicity, consistency and rationality; accessibility and sufficient level of complexity; connection between theory and practice determines the requirements of the organization of the students' individual educational activities system to lecturers, students, didactic system, links and interrelations among different components of education at a higher educational institution.

The implementation of the elaborated system of principles of organization of individual educational activity of students at higher educational institutions will provide the theoretical basis and practical implementation of pedagogical system as well of an integral pedagogical model of organization of individual educational activity of students at higher educational institutions.

Keywords: development; autonomy; the students' autonomy development; an integration; educational and self-educational activities; higher education.

$\Pi$ остановка проблеми. Впровадження у практикуновітніх інноваційнихпідходів та подачі інформації, яка дуже швидко оновлюється, вимагають від майбутніх учителів здатності самостійно й мобільно приймати найрізноманітніші рішення стосовно значної кількості нетрадиційних педагогічних задач i завдань, які можуть постати перед ними у власній педагогічній діяльності. Аби почуватися впевнено майбутній учитель має набути сталих здібностей щодо самоактуалізації й самореалізації ще під час навчання у закладі вищої освіти, які стануть показниками самоефективності на шляху самовдосконалення його особистості. Власний аналіз наукового феномену становлення проблеми розвитку автономності особистості в діяльності ми розпочинаємо із занурення в історикодидактичний контекст цієї проблеми. 


\begin{abstract}
Аналіз останніх досліджень і публікацій. Автономність особистості як предмет дослідження певною мірою представлена у роботах О. Дергачової, Е. Десі, Д. Леонтьєва, Ж. Пижикової, Г. Пригіна, Т. Партико, Р. Райана, О. Сергєєвої, зокрема, в контексті суб'єктності (І. Котик, А. Марічева та ін.), довільної саморегуляції (Ж. Вірна, В. Ілійчук, С. Малазонія, Ю. Миславський), суверенності особистості (А. Клочко, С. Нартова-Бочавер), автентичності (Н. Когутяк, М. Рагуліна), особистісної ідентичності юнака (Л. Клочек, Ю. Лановенко, I. Середницька та ін.).
\end{abstract}

Мета статті - здійснити аналіз сукупності принципів розвитку автономності студентів в умовах інтеграції освітньої й самоосвітньої діяльності.

Виклад основного матеріалу. Поряд iз загальнодидактичними принципами, дотримання яких необхідно при використанні існуючих організаційних форм, методів і засобів навчання нині в педагогічній літературі достатньо грунтовно висвітлені принципи контекстного навчання в поєднанні з принципами конструктивізму в освіті, модульності, оптимізації колективних, групових і індивідуальних форм організації навчального процесу, пріоритету функціональної взаємодії навчальних компонентів практико-орієнтованої освітньої діяльності на всіх рівнях засвоєння навчального матеріалу і розвитку соціальноосвітнього досвіду студентів та інші. Тож перш, ніж назвати принципи розвитку автономності студентів в умовах інтеграції освітньої та самоосвітньої діяльності, конкретизуємо, поперше, загальні принципи навчання у вищій школі та принципи контекстного навчання (А. Вербицький) [3] як вислід концептуальної ідеї контекстнопредметного навчання і по-друге, загальні принципи формування особистості студента (А. Столяренко) [11].

М. Данілов характеризує дидактичні принципи як нормативні основи навчання, взяті в конкретноісторичному вигляді. Для Ш. Ганеліна принципи навчання - це вихідні положення, які лежать в основі навчання і визначають всі його сторони: зміст, форми організації, методи; вони виводяться із закономірностей навчального процесу наукового осмислення дидактичної спадщини минулого і узагальнення сучасної практики навчання [5].

Визнаючи, що класичні дидактичні принципи зберігають свою цінність і у вищій школі, науковці модернізують і доповнюють їх. Так, I. Кобиляцький у слов'янському освітньому просторі перший формулює дидактичний принцип забезпечення єдності наукової і навчальної діяльності студентів [7]. У сучасних працях 3 дидактики вищої школи, як правило, наводиться перелік принципів навчання, які мають дидактичну, організаційну, психологічну основи. М. Буланова-Топоркова визначає принципи навчання у вищій школі як синтез всіх існуючих дидактичних принципів. До числа таких належать:

- орієнтованість вищої освіти на розвиток особистості майбутнього фахівця;

- відповідність змісту вузівської освіти сучасним і прогнозованим тенденціям розвитку науки (техніки) і виробництва (технологій);

- оптимальне поєднання загальних, групових та індивідуальних форм організації навчального процесу у ЗВО;

- раціональне застосування сучасних методів і засобів навчання на різних етапах підготовки фахівців;

- відповідність результатів підготовки фахівців вимогам, які пред’являються конкретною сферою їх професійної діяльності, забезпечення їх конкурентоспроможності $[1,44]$.

М. Гарунов, Л. Семушкіна, Ю. Фокін виокремлюють групи “стратегічних принципів навчання у вищій школі', а саме:

- орієнтованість вищої освіти на розвиток особистості майбутнього спеціаліста;

- відповідність змісту вузівського навчання сучасним тенденціям розвитку науки (техніки) i виробництва (технологій) та тенденціям, що прогнозуються;

- оптимальне поєднання загальних, групових, індивідуальних форм організації навчального процесу у закладі вищої освіти;

- раціонального застосування сучасних методів та засобів навчання на різних етапах підготовки спеціаліста;

- відповідність результатів підготовки спеціалістів вимогам, які висуваються конкретною сферою їх професійної діяльності, забезпечення їх конкурентоздатності (цитата за джерелом [10]).

До числа основних принципів контекстного навчання відносять:

- принцип педагогічного забезпечення особистісного включення студента в навчальну діяльність;

- принцип послідовного моделювання у навчальній діяльності студентів цілісного змісту, форм і умов професійної діяльності фахівців;

- принцип проблемності змісту навчання i процесу його розгортання в освітньому процесі;

- принцип адекватності форм організації навчальної діяльності студентів цілям і змісту освіти; 
- принцип провідної ролі спільної діяльності, міжособистісної взаємодії і діалогічного спілкування суб'єктів освітнього процесу (викладача і студентів, студентів між собою); - принцип педагогічно обгрунтованого поєднання нових і традиційних педагогічних технологій;

- принцип єдності навчання і виховання особистості професіонала [2].

До основних педагогічних принципів формування особистості, за О. Столяренко, належать:

1. Принцип цілеспрямованого, всебічного i гармонійного формування особистості в інтересах

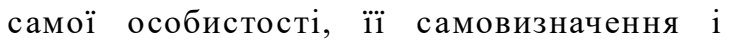
самореалізації в житті, а також в інтересах суспільства і держави.

2. Принцип науковості у формуванні особистості. Складність і сумний досвід стихійного, неосмисленого, заснованого тільки на життєвих уявленнях формування особистості вимагають підходити тільки 3 достовірних, викристалізуваних в позитивному досвіді і втілених в педагогічних і психологічних рекомендаціях позицій. 3 діями на основі особистих домислів і дрімучої педагогічної некомпетентності треба рішуче покінчити. Занадто велика ціна упущень і помилок в особистій долі формується людини, які дуже важко, а часом і неможливо потім усунути.

3. Принцип максимального наближення цілей, змісту, методів, умов формування особистості до рівня досягнень світової цивілізації на основі загальнолюдських цінностей, творення, світу, моралі, національної гідності, державності.

4. Принцип безперервності і наступності формування особистості в процесі життя 3 підвищеною увагою до дитячого, підліткового і юнацького віку і максимальним подоланням стихійних, неконтрольованих педагогічних впливів.

5. Принцип системності, взаємопов'язаного формування чотирьох основних педагогічних властивостей особистості - освіченості, вихованості, навченості, розвиненості та відповідної організації чотирьох, пов'язаних єдиною метою і обслуговуючих один одного педагогічних підсистем - освіти, виховання, навчання і розвитку.

6. Принцип єдності педагогічних впливів і самоформування особистості. Ніхто не може зробити людину такою, якою вона не хоче бути i протидіє цьому, формування - це суб'єктсуб'єктний процес, взаємодія суб'єкта педагогічних впливів і формується - їх об'єкта, що є разом з тим суб'єктом, особистістю зі своїми поглядами, інтересами, бажаннями, ідеалами, планами. Успіх можливий лише при збігу їх цілей і зусиль, при тісній співпраці, при обопільній і злагодженій активності, при цілеспрямованій активності формується потім самоформування.

7. Принцип випереджаючого формування особистості в дусі основних тенденцій суспільного розвитку: гуманізму, демократизму, законності, громадянськості.

8. Принцип формування культурності особистості: естетичної, етичної, екологічної, сімейної, побуту і здоров'я $[11,85]$.

Базові принципи враховують особливості системно-дидактичного забезпечення в умовах модернізації вищої школи,як наслідок маємо такі вихідні положення: цілі і зміст дидактичного забезпечення конкретної навчальної дисципліни розробляються на основі моделі діяльності фахівця, що включає основні функції, завдання, проблеми, об'єкти майбутньої спеціальності; структура та функції реальної предметної діяльності, виражені в моделі фахівця, задають системоутворюючий контекст змісту дидактичного забезпечення не тільки окремих навчальних дисциплін, а й підготовки фахівця в цілому; орієнтація всіх освітніх процедур на гарантоване досягнення навчальних цілей, повне рішення поставлених дидактичних завдань; оцінка підсумкових результатів навчання, інтерактивний зв'язок в системі “викладач-студент” здійснюються як 3 позицій сукупності набутих знань, умінь і навичок щодо вирішення конкретних професійних завдань, так і з позицій зміни особистісного досвіду щодо моделі діяльності.

Усе, сказане вище надає нам вагомі підстави для того, щоб сформулювати принципи розвитку автономності студента в умовах інтеграції освітньої та самоосвітньої діяльності:

1. Принцип єдності соціалізації та професіоналізації особистості в автономній діяльності. Шляхи реалізації цього принципу витікають 3 визначень соціалізації як процесу становлення особистості й професіоналізації, яка означає "педагогічно регульований процес професійного становлення особистості, який цілком і повністю відповідає сучасним вимогам у певній галузі діяльності” [9].

2. Принции наступності станів та видів діяльності “доавтономної” - “автономної” “позаавтономноі”. В освітній та самоосвітній діяльності зберігається зв'язок якісно різних стадій навчання, різних як за змістом, так і за способами представлення. У вищій школі форма і зміст знань, а також умови інтеріоризації цих знань відрізняються від тих, які розповсюджені у 
старшій профільній школі. Та якісні відмінності окремих стадій інтеріоризації не повинні заступати загального принципу наступності у розвитку автономності як важливого професійноособистісного новоутворення студентського віку. Принцип наступності передбачає поступовість та взаємопроникнення станів “доавтономної діяльності”, власне автономної діяльності студента та "позаавтономної” діяльності.

3. Принцип свідомості автономної діяльності. Класичний дидактичний принцип свідомості повинен реалізовуватися студентом в автономній діяльності: студенти отримують знання не в готовому вигляді, а досліджують умови (історію) їх виникнення, сучасний стан, самостійно розв'язують навчальні проблеми, чітко розуміючи важливість іпотрібність засвоєної інформації. Ш. Ганелін, який у XX столітті, спираючись на методичні досягнення своїх попередників, науково переосмислив місце і роль принципу свідомості в загальній дидактичній архітектоніці, розбудовує цілісну дидактичну систему саме на основі вивчення механізмів реалізації принципу свідомості: прояв цього принципу як основного у формуванні світогляду суб'єктів учіння, здійснення принципу свідомості в окремих ланках навчання, реалізація принципу свідомості у самостійній діяльності [4]. Під свідомістю Ш. Ганелін розуміє такий принцип дидактики, за допомогою якого “забезпечується грунтовне знання фактів, визначень, законів, глибоке осмислення висновків, узагальнень 3 умінням правильно виразити свої думки в мовленні, перетворення знань в переконання, i уміння самостійно використовувати знання на практиці" [4]. Свідомість є важливим засобом подолання формалізму знань. Реалізація принципу свідомості вимагає активізації розумової діяльності, виховання активності, самостійності у здобутті знань.

Кожна наука, навчальна дисципліна, маючи справу з особливою феноменологією реальності, використовує і особливу термінологію. Автономна діяльність потребує розуміння студентами значення кожного спеціального терміна або поняття, інакше така діяльність приречена на неуспіх. Навіть відомі слова, що мають ключове значення при вивченні певного питання, потребують того, щоб повсякденне розуміння їх значення було підняте до наукового і стало б максимально однаковим у викладача і студентів. Досвідчені викладачі-практики кажуть: в кожному розумінні є частка нерозуміння. Щоб ця частка була принаймні мінімальна, автономній діяльності студента повинна передувати робота 3 докладного і точного розуміння, розкритті значення нових термінів і понять, перевірці викладачем ступеня свідомого оперування певним поняттям. Саме принцип свідомості автономної діяльності дозволяє переосмислити зв'язок знань і способів діяльності, розуміння і ставлення, системи знань, розвитку мислення й світогляду.

Свідомо готуватися до майбутньої професійної діяльності - значить розвивати необхідні здібності, вдосконалювати свої розумові якості. Для студентства діяльність навчання є провідною діяльністю. Але вміння і прагнення вчитися, а головне - бажання оволодіти конкретною професією, як правило, не виникають спонтанно самі по собі в зв'язку з зарахуванням абітурієнтів до закладів вищої освіти. Тільки бажання оволодіти професією не є надійною гарантією формування професійних якостей. Абітурієнт, як правило не уявляє собі, що становить сутність його майбутньої професії, яких знань, умінь, навичок і здібностей вона вимагає, яка система підготовки призведе до оволодіння спеціальністю і формування потрібних рис особистості. I тому школярі, які у вуз за формальними мотивами, прирікають себе до певної міри на помилку вибору, що згодом позначається на їх навчанні та професійній підготовці. Більшість вступають до 3ВО без урахування особистих можливостей і специфіки майбутньої професії, лише з бажання здобути вищу освіту, або престижності вузу і спеціальності, або невисокого конкурсу, або за компанію $з$ друзями. Для становлення студента як фахівця потрібні відповідні передумови, основними індикаторами яких можуть бути професійна спрямованість і відповідна довузівська підготовка молоді. Свідоме позитивне ставлення, інтерес до професії, схильність займатися нею забезпечують успіх розвитку автономності.

\section{4. Принцип професійно оріснтованої} мобільності студента в автономній діяльності. У сучасних євроінтеграційних документах знаходимо опис різних видів мобільності в освіті, ми ж використовуємо цей термін для визначення стану динамічної свободи студента в автономній діяльності.

Саме в автономній діяльності знаходить втілення педагогічне гасло “дисципліна через свободу, яке сформульоване в працях західноєвропейських та слов'янських педагогів (М. Монтессорі [8], П. Каптерев [6]). Надаючи педагогічне пояснення цього положення, італійська вчена, педагог-експериментатор М. Монтессорі зауважувала: “дисципліна у свободі - той великий принцип, який нелегко зрозуміти прихильникам традиційних методів... Зрозуміло, 


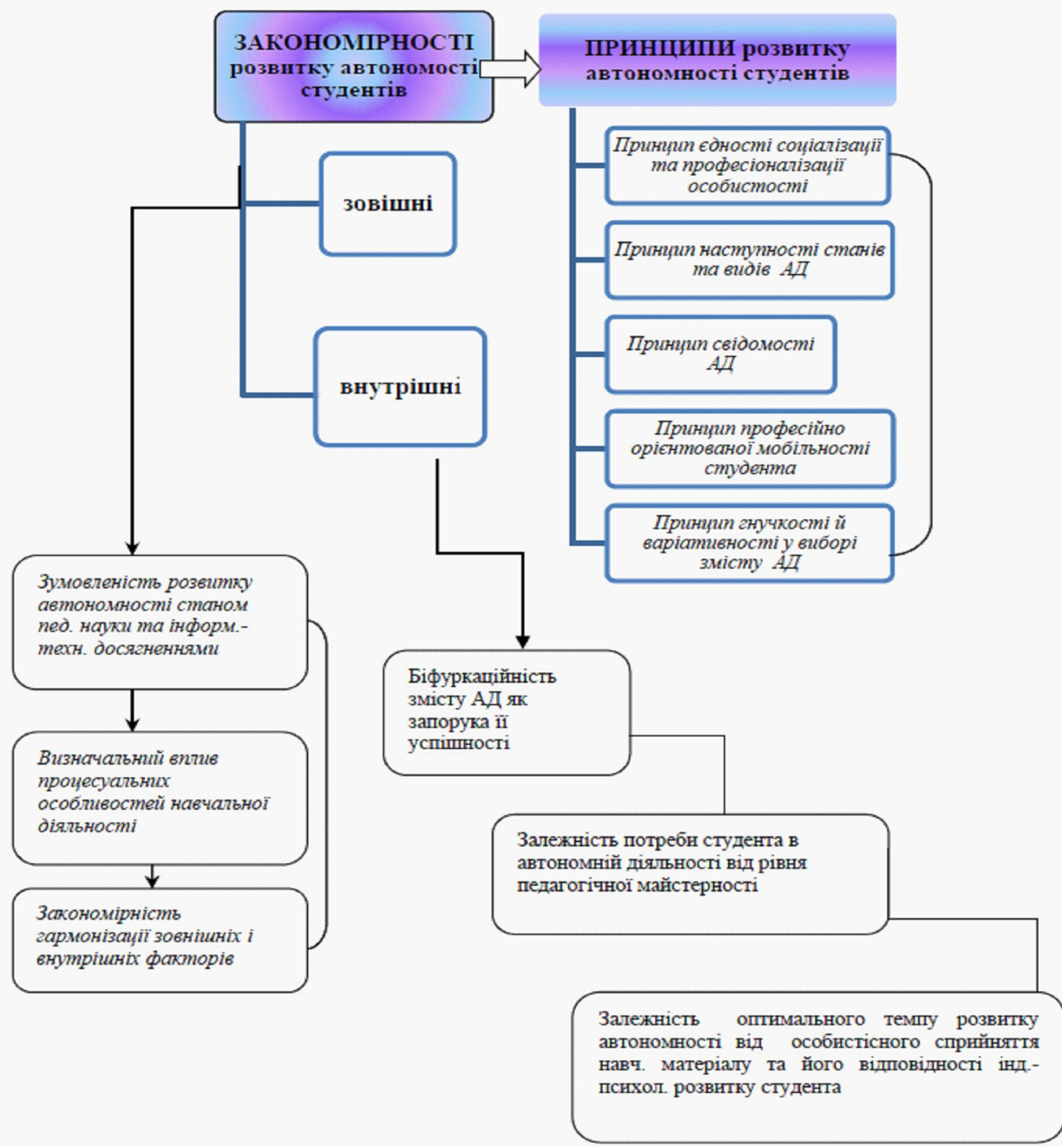

Рис. 1. Закономірності та принципи розвитку автономності студентів в умовах інтеграції освітньої та самоосвітньої діяльності

в нашій системі поняття дисципліни вельми відрізняється від розповсюдженого іiї розуміння. Оскільки дисципліна заснована на свободі, то і сама дисципліна обов'язково повинна бути діяльною, активною. Зазвичай ми вважаємо індивіда дисциплінованим тільки з тієї пори, як він стане мовчазним, як німий, і нерухомим, як паралітик. Але в такому разі особистість знищена... Ми називаємо людину дисциплінованою, коли вона володіє собою і вміє узгодити свою поведінку з необхідністю дотримуватися того чи того... правила" [8, 108]. Коли діяльність виконується без зовнішнього примусу й виконується студентом якісно - це і є динамічна свобода студента.

5. Принцип гнучкості й варіативності у виборі змісту автономної діяльності. Більшість професійних дій має складну, багатокомпонентну структуру: вони складаються 3 ряду послідовно здійснюваних часткових дій, операцій, прийомів (число яких доволі значне). Опановувати такими діями не просто. Склалися три системи подолання цієї складності: предметна, операційна і предметно-операційна (комплексна). Суть предметної системи - у вимозі до тих, хто навчається, виконувати дію, що засвоюється, 
завжди у цілому. Для освоєння простих дій така система є цілком виправданою, а відпрацювання складних затягується, якість виконання окремих операцій виявляється низьким. Операційна система навчання характерна послідовної відпрацюванням до досконалості кожного складового елементу дії. До виконання дії в цілому переходять тільки після відпрацювання всіх операцій. Ця система вимагає дуже великого часу, і виникають труднощі в об'єднанні відпрацьованих окремо прийомів і операцій в цілісну навичку. Предметно-операційна (комплексна) система з'єднує достоїнства попередніх двох систем і зводить до мінімуму їх недоліки. Викладач добре представляє труднощі оволодіння тією чи тією навичкою і знає, що зазвичай не дуже вдається студентам, вирішує, які операції треба відпрацювати окремо. Таке відпрацювання можна провести спочатку або після двох-трьох загальних спроб. Після цього завершується відпрацювання дії в цілому. Така система найбільш придатна для відпрацювання складних дій (О. Столяренко [11]). Тож саме принцип гнучкості й варіативності забезпечує технолого-процесуальну результативність формування автономності студентів.

Далі, на схемі ми наочно представляємо загальний перелік закономірностей та принципів розвитку автономності студентів в умовах інтеграції освітньої та самоосвітньої діяльності.

Як показують спеціальні дослідження, у вищій школі основна увага приділяється саме предметним знанням, в той час як причини помилок при вирішенні навчальних і професійних завдань дуже часто зумовлені недостатнім розвитком логічного мислення, логічної підготовки або криються в невмінні планувати і контролювати свою діяльність. Це пов'язано з тим, що зазначені аспекти професійної підготовки часто спеціально не виділяються в якості особливого навчального завдання, в силу чого відповідні знання та вміння складаються стихійно і мають погані показники за низкою параметрів.

Висновки і пропозиції. Визначальну роль в організації навчання у вищому навчальному закладі відіграють наукові теорії, а не практика. Але теорію, для того щоб вона не залишалась абстрактною, слід будувати на основі вже накопиченого студентами досвіду, спиратись на нього, розвивати його. Після вивчення певних теоретичних положень, необхідно надати їм вихід у практику, довести теоретичні положення до стадії дій, операцій, процедур, технологій, формувати в студентів уміння й навички практичного застосування отриманих знань. Саме дотриманню всіх перерахованих вимог взаємозв'язку теорії й практики має відповідати процес організації самостійної освітньої діяльності студентів закладів вищої освіти.

Здійснений аналіз сукупності принципів самостійності; гуманізації й гуманітаризації; наступності; науковості; свідомості й активності; системності, послідовності й раціональності; доступності й достатнього рівня складності; зв’язку теорії з практикою; визначають вимоги системи організації самостійної освітньої діяльності студентів до викладачів, студентів, до дидактичної системи, до зв'язків і взаємовідношень між компонентами навчання у закладі вищої освіти.

Реалізація розробленої системи принципів організації самостійної освітньої діяльності студентів закладів вищої освіти забезпечить теоретичне обгрунтування й практичну реалізацію педагогічної системи, а також цілісної педагогічної моделі організації самостійної освітньої діяльності студентів закладів вищої освіти.

\section{ЛІТЕРАТУРА}

1. Буланова-Топоркова М. В. Педагогика и психология высшей школы / М. В. БулановаТопоркова. - Ростов-на-Дону: Феникс, 2002. - 342 с.

2. Вербицкий А. А. Активное обучение в высшей школе: контекстный подход / А.А.Вербицкий. - М.: Высшая школа, 1991. - 207 с.

3. Вербицкий А. А. Новая образовательная парадигма и контекстное обучение / А. А. Вербицкий. - М.: Исследовательский центр проблем качества подготовки специалистов. - 1999. - 75 с.

4. Ганелин Ш.И. Дидактический принцип сознательности. М.: Изд-во АПН РСФСР, 1961. $-223 \mathrm{c}$.

5. Данилов М. А. Теоретические основы и методы фундаментальних педагогических исследований / М. А. Данилов. - М., 1972.

6. История педагогики и образования. От зарождения воспитания в первобытном обществе до конца XX в. / [Пискунов А.И., Вендровская Р.Б., Кларин В.М. и др.]; под ред. А.И.Пискунова. - М.: ТЦ Сфера, 2001. - 512 с.

7. Кобыляцкий И. И. Педагогика высшей школы / И.И. Кобыляцкий. - К.: Вища школа, 1978. $-286 \mathrm{c}$.

8. Монтессори М. Метод научной педагогики / М. Монтессори // Антология гуманной педагогики. - М., 1999. - 108 с.

9. Новейший психолого-педагогический словарь / сост. Е. С. Рапацевич; под общ. ред. А. П. Астахова. - Минск: Современная школа, 2010. $-928 \mathrm{c}$.

10. Садова В. В. Фундаменталізація змісту педагогічних дисциплін у підготовці майбутніх 
учителів початкової школи: теоретикометодологічні аспекти: монографія / В.В. Садова. - Кривий Ріг, 2016. - 392 с.

11. Столяренко А. М. Психология и педагогика / А. М. Столяренко. - М.: ЮНИТИ-ДАНА, 2001. $-423 \mathrm{c}$.

\section{REFERENCES}

1. Bulanova-Toporkova, M. V. (2002). Pedagogika $i$ psikhologiya vysshey shkoly [Pedagogy and Psychology of the Higher School]. Rostov-na-Donu: Feniks, 342 p. [in Russian].

2. Verbitskiy, A. A. (1991). Aktivnoe obuchenie $v$ vyisshey shkole: kontekstnyiy podhod [Active Learning in Higher School: Context Approach]. Moscow: Vyisshaya shkola Publ., 207 p. [in Russian].

3. Verbitskiy, A. A. (1999). Novaya obrazovatelnaya paradigma $i$ kontekstnoe obuchenie [New Educational Paradigm and Context Learning]. Moscow: Centre for Studies of the Specialists, Training Quality Problems, 75 p. [in Russian].

4. Ganelin, Sh. I. (1961). Didakticheskiy printsip soznatelnosti [Instructional Principle of Awareness]. Moscow: APN RSFSR Publ., 223 p. [in Russian].

5. Danilov, M. A. (1972). Teoreticheskie osnovyi $i$ metodyi fundamentalnih pedagogicheskih issledovaniy [Theoretical Framework and Methods of the Fundamental Pedagogical Researches]. Moscow [in Russian].

6. Piskunov, A.I., Vendrovskaya, R.B. \& Klarin, V. M. et al (2001). Istoriya pedagogiki i obrazovaniya.
Ot zarozhdeniya vospitaniya $v$ pervobyitnom obschestve do kontsa XX st. [History of Pedagogy and Education. From the Early Days of Upbringing in a Primitive Society till the End of the $20^{\text {th }}$ Century]. (Ed.). A. I. Piskunova. Moscow: TTs Sfera Publ., 512 p. [in Russian].

7. Kobyilyatski, I. I. (1978). Pedagogika vyisshey shkolyi [Pedagogy of the Higher School]. Kyiv: Vischa shkola Publ., 286 p. [in Russian].

8. Montessori, M. (1999). Metod nauchnoy pedagogiki [The Scientific Pedagogy Method]. Antologiya gumannoy pedagogiki [The Anthology of Humane Pedagogy]. Moscow, 108 p. [in Russian].

9. Rapatsevich, E. S. \& Astahova, A. P. (Ed.). (2010). Noveyshiy psihologo-pedagogicheskiy slovar [Updated Psychological and Pedagogical Dictionary]. Minsk: Sovremennaya shkola Publ., 928 p. [in Russian].

10. Sadova, V. V. (2016). Fundamentalizatsiia zmistu pedahohichnykh dystsyplin u pidhotovtsi maibutnikh uchyteliv pochatkovoi shkoly: teoretyko-metodolohichni aspekty: monohrafiia [Fundamentalization of the Content of the Psychological Disciplines in the Training of a Future Primary School Teachers: Theoretical and Methodological Perspective: Research Monograph]. Kryvyi Rih, 392 p. [in Ukrainian].

11. Stolyarenko, A. M. (2001). Psihologiya $i$ pedagogika [Psychology and Pedagogy]. Moscow: YuNITI-DANA Publ., 423 p. [in Russian].

Стаття надійшла до редакції 25.07.2018

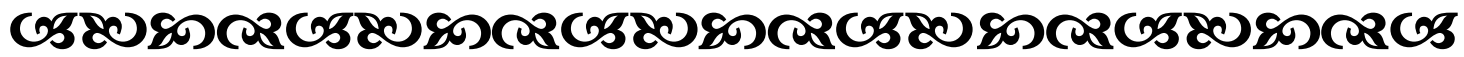

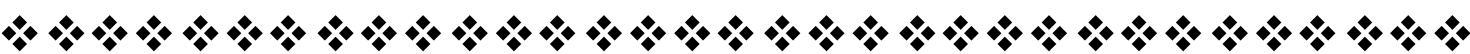

"Успіх однієї відважної людини завжди спонуқає до завзяття й мужності иіле поқоління".

$$
\begin{array}{r}
\text { Оноре де Бальзак } \\
\text { браниузький романіст і драматург }
\end{array}
$$

“Хіба буває щось преқрасне чи негарне саме по собі? Чٓо подобається юині, те для неї й преқрасне".

Dавньоіндійсьқа мудрість

"Яћще ви володієте знанням, дайте іншим запалити від нъого свої світильники".

Томас Фулиер англійсьжий філособ і письменник

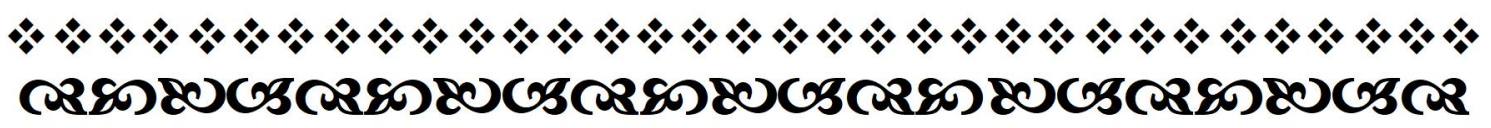

Молодь і ринок №9 (164), 2018 